\title{
16. THE TRACE ELEMENT BUDGET OF THE EASTERN MEDITERRANEAN DURING PLIOCENE SAPROPEL FORMATION ${ }^{1}$
}

\author{
Ivar A. Nijenhuis, ${ }^{2}$ H.-J. Brumsack, ${ }^{3}$ and G.J. De Lange ${ }^{2}$
}

\begin{abstract}
Geochemical data are presented from an organic-carbon-rich Pliocene sapropel (i-282) from three different Leg 160 sites (Sites 964, 967, and 969). The geochemical characteristics of this sapropel are comparable to those of previous studies, except for the very high organic carbon and trace element contents. The high organic carbon is explained by both increased productivity and improved preservation. Estimates of the trace element budget during formation of this sapropel suggest that a marine trace element source must have been most important. Other sources that contributed are river input and diagenesis; eolian input and hydrothermal activity can be disregarded. Most trace elements that were supplied to the Eastern Mediterranean during the formation of this sapropel probably ended up in the sediment. Thus, an effective mechanism of transfer of these elements from seawater to sediment was operative. This mechanism is thought to be scavenging by organic matter and sulfides under widespread anoxic conditions. Results of analyses of Sapropel i-292 from Sites 964, 966, and 967 were similar, thus these characteristics are not unique to the i-282 sapropel.
\end{abstract}

\section{INTRODUCTION}

Eastern Mediterranean Neogene sediments are characterized by the cyclic occurrence of organic-rich layers: sapropels, laminites, or "gray layers" in carbonate cycles. Langereis and Hilgen (1991), for example, demonstrated that cyclicity in Mediterranean sediments correlates to variations in the eccentricity of Earth's orbit and the obliquity and precession of Earth's axis. Because of the dominance of precession in this area, one cycle of organic-rich sediment (subsequently referred to as sapropel) and homogeneous sediment deposition lasts 23 k.y., on average. Studies of these layers are performed either on recent sapropels recovered from the seafloor by gravitycoring techniques (e.g., Rossignol-Strick et al., 1982; Calvert, 1983; Thomson et al., 1995), or on Pleistocene and older sediments found in sections on land, mostly on Mediterranean islands such as Sicily, Crete, and Gavdos (e.g., Van der Weijden, 1993; Van Os et al., 1994; Nijenhuis et al., 1996). In both cases, sapropels are characterized by a decrease in the carbonate fraction, an increase in the clay fraction, and organic carbon contents generally on the order of a few percent.

During Ocean Drilling Program (ODP) Legs 160 and 161 to the Eastern and Western Mediterranean, hydraulic drilling techniques were used to obtain not only the younger sapropels, but also older (down to lower Pliocene) sediments from the seafloor. During Leg 160 , the striking observation was made that some of the recovered Pliocene sapropels have very high organic carbon contents, up to 30 wt\% (Emeis, Robertson, Richter, et al., 1996). Sediments with such high organic contents are also often enriched in trace elements, including $\mathrm{Co}, \mathrm{Cr}, \mathrm{Cu}, \mathrm{Mo}, \mathrm{Ni}, \mathrm{V}$, and $\mathrm{Zn}$. A thorough investigation of these trace element occurrences can reveal paleoceanographic conditions at the time of sediment deposition. Successful examples are the trace element budget calculations performed for several black shales (Arthur et al., 1990; Brumsack, 1980, 1986), and for the Gulf of California and the Black Sea (Brumsack, 1989).

${ }^{1}$ Robertson, A.H.F., Emeis, K.-C., Richter, C., and Camerlenghi, A. (Eds.), 1998. Proc. ODP, Sci. Results, 160: College Station, TX (Ocean Drilling Program).

${ }^{2}$ Institute of Earth Sciences, Department of Geochemistry, Utrecht University, Budapestlaan 4, P.O. Box 80.021, 3508 TA Utrecht, The Netherlands. ian@earth.ruu.nl

${ }^{3}$ Institute of Chemistry and Biology of the Marine Environment, Department Microbiogeochemistry, Oldenburg University, P.O. Box 2503, 26111 Oldenburg, Federal Republic of Germany.
We present data from a Pliocene sapropel that has very high organic carbon (up to $27 \mathrm{wt} \%$ ) and trace element contents. These data will be used to estimate a trace element budget for the Eastern Mediterranean during the formation of this sapropel.

\section{MATERIALS AND METHODS}

The sapropel selected for this study is from MPRC Cycle 282 (i282), astronomically dated at $2.943 \mathrm{Ma}$, late Pliocene (Piacenzian; Lourens et al., 1996). It can be identified unambiguously in Sites 964, 967, and 969 (L. Lourens, pers. comm., 1997). This sapropel will be compared with that of MPRC Cycle 292 (i-292), dated at $3.058 \mathrm{Ma}$ (Lourens et al., 1996). The intervals selected and abbreviations used to describe them are listed in Table 1.

Slices $0.5-2 \mathrm{~cm}$ thick were cut from the split cores using Teflon cutters. The slices were freeze dried, after which subsamples were taken. These subsamples were crushed and homogenized in an agate mortar, and subsequently used for all further geochemical analyses.

Before and after removal of inorganic carbon using $1 \mathrm{M} \mathrm{HCl}$, carbon and nitrogen contents were measured using a Fisons NA 1500 NCS analyzer. The carbonate content of the samples was approximated by converting all $\mathrm{C}_{\text {inorg }}\left(\mathrm{C}_{\mathrm{tot}}-\mathrm{C}_{\text {org }}\right)$ to $\mathrm{CaCO}_{3}$. The stable carbon isotope composition of the organic matter $\left(\delta^{13} \mathrm{C}_{\mathrm{org}}\right)$ was determined

Table 1. Specification of the intervals used in this study.

\begin{tabular}{|c|c|c|c|}
\hline $\begin{array}{l}\text { Core, section, } \\
\text { interval }(\mathrm{cm})\end{array}$ & $\begin{array}{c}\text { Sapropel } \\
\text { location }(\mathrm{cm})\end{array}$ & Abbreviation & Cycle \\
\hline $\begin{array}{l}\text { 160-964D- } \\
10 \mathrm{H}-1,90-132.5\end{array}$ & $103-110$ & 964D10/1 & i- 282 \\
\hline $\begin{array}{l}\text { 160-967C- } \\
8 \mathrm{H}-1,95-151\end{array}$ & $114-130$ & $967 \mathrm{C} 8 / 4$ & i- -282 \\
\hline $\begin{array}{l}160-969 \mathrm{E} \\
6 \mathrm{H}-6,19-52\end{array}$ & $26-40$ & $969 \mathrm{E} / 6$ & i- 282 \\
\hline $\begin{array}{l}\text { 160-964E- } \\
6 \mathrm{H}-5 / 6,128-045\end{array}$ & $5-13$ & $964 \mathrm{E} 6 / 5$ & i-292 \\
\hline $\begin{array}{l}\text { 160-966C- } \\
5 \mathrm{H}-3 / 4,135-025\end{array}$ & $147-016$ & $966 C 5 / 3$ & i-292 \\
\hline $\begin{array}{l}160-967 \mathrm{C}- \\
8 \mathrm{H}-6,26-68\end{array}$ & $37-58$ & $967 C 8 / 6$ & i-292 \\
\hline
\end{tabular}

Note: Cycle coding after Lourens et al., 1996. 
using a Stable Isotope Ratio Analyzer (VG SIRA 24) and is reported relative to the PeeDee belemnite (PDB) standard (\%o).

For major, minor, and trace element analyses, a 250-mg sample was digested in $10 \mathrm{~mL}$ of a 6.5:2.5:1 mixture of $\mathrm{HClO}_{4}(60 \%), \mathrm{HNO}_{3}$ $(65 \%)$, and $\mathrm{H}_{2} \mathrm{O}$, and $10 \mathrm{~mL}$ of $\mathrm{HF}(40 \%)$ at $90^{\circ} \mathrm{C}$. After evaporation of the solutions at $190^{\circ} \mathrm{C}$ on a sand bath, the dry residue was dissolved in $50 \mathrm{~mL}$ of $1 \mathrm{M} \mathrm{HCl}$. The resulting solutions were analyzed with a Perkin Elmer Optima 3000 inductively coupled plasma-atomic emission spectrometer (ICP-AES) to measure Al, Fe, S, Ba, Mn, Mo, $\mathrm{V}, \mathrm{Cu}, \mathrm{Co}, \mathrm{Ni}, \mathrm{Zn}$, and $\mathrm{Cr}$. As, $\mathrm{Se}$, and $\mathrm{Sb}$ were measured in the same solutions using a Perkin Elmer 3100 hydride-atomic absorption spectrometer (AAS); Cd was measured using a Perkin Elmer 4100 ZL ZGFAAS.

All results were checked using international (a.o. SO1, MAG-1) and in-house (MMM 91) standards. For organic carbon and total nitrogen analyses, relative standard deviations in duplicate measurements are less than $6 \%$; for $\delta^{13} \mathrm{C}$, they are less than $1 \%$. ICP duplicate measurements have relative standard deviations greater than $4 \%$ for all elements presented. $\mathrm{As}, \mathrm{Se}, \mathrm{Sb}$, and $\mathrm{Cd}$ were measured in triplicate. Relative standard deviations for $\mathrm{As}$ and $\mathrm{Cd}$ are always below $5 \%$; for $\mathrm{Se}$ and $\mathrm{Sb}$, they are below $10 \%$ for sediment contents over 1 ppm.

\section{RESULTS}

The results for interval 160-964D-10H-1, 90-132.5 cm, are shown graphically (Figs. 1, 2); because the patterns for the other three intervals are similar, only mean and extreme values are given (Table 2).

Organic carbon (Fig. 1) is enriched in the dark intervals, reaches values of $15 \mathrm{wt} \%$ in interval 967C8/4 (Table 1) and of more than 25 $\mathrm{wt} \%$ in the other two intervals. These high $\mathrm{C}_{\mathrm{org}}$ values are accompanied by higher $\mathrm{C}: \mathrm{N}$ values (up to 23), lower $\delta^{13} \mathrm{C}$ values (down to $-24 \%$ o $\mathrm{PDB}$ ), and high Ba contents (up to $1400 \mathrm{ppm}$ in interval 969E6/6).
Carbonates are strongly depleted in the sapropels, decreasing from $\sim 65$ $\mathrm{wt} \%$ in the homogeneous intervals to less than $25 \mathrm{wt} \%$ in intervals rich in total organic carbon (TOC). Aluminum (Fig. 1), which can be considered representative of terrestrial components, shows complex profiles for most intervals. The Fe:Al and S profiles (Fig. 1) show good correlation. (Terrestrial and trace elements are presented as ratios to $\mathrm{Al}$ to correct for dilution effects.) The highest contents of the trace elements As, Cd, Co, Cr, Cu, Mo, Ni, Sb, Se, V, and Zn (Fig. 2) are reached within the sapropels; however, in several cases, elevated trace element contents also occur in homogeneous intervals. The Mn:Al profile (Fig. 1) is characterized by a decrease in the sapropels.

\section{DISCUSSION}

Although the geochemical patterns of the sapropels of this study are typical of Mediterranean sapropels, such high $\mathrm{C}_{\text {org }}$ and trace element values have not been reported previously (Calvert, 1983; Sutherland et al., 1984; Pruysers et al., 1991; Van der Weijden, 1993; Thomson et al., 1995; Nijenhuis et al., 1996).

Organic carbon enrichment in sapropels has been explained by two fundamental mechanisms:

1. increased production of marine organic matter and/or enhanced input of terrestrial organic matter (e.g., Calvert, 1983; Pedersen and Calvert, 1990), or

2. improved preservation of organic matter as a result of bottomwater anoxia (e.g., Olausson, 1961; Cita et al., 1977; Demaison and Moore, 1980).

Evidence that has been adduced for increased productivity comprises occurrences of eutrophic planktonic foraminiferal species and increased concentrations of barium, an indicator of geochemical paleoproductivity. Plausible arguments for anoxic bottom-water conditions include the occurrence of laminae in the sapropels, more

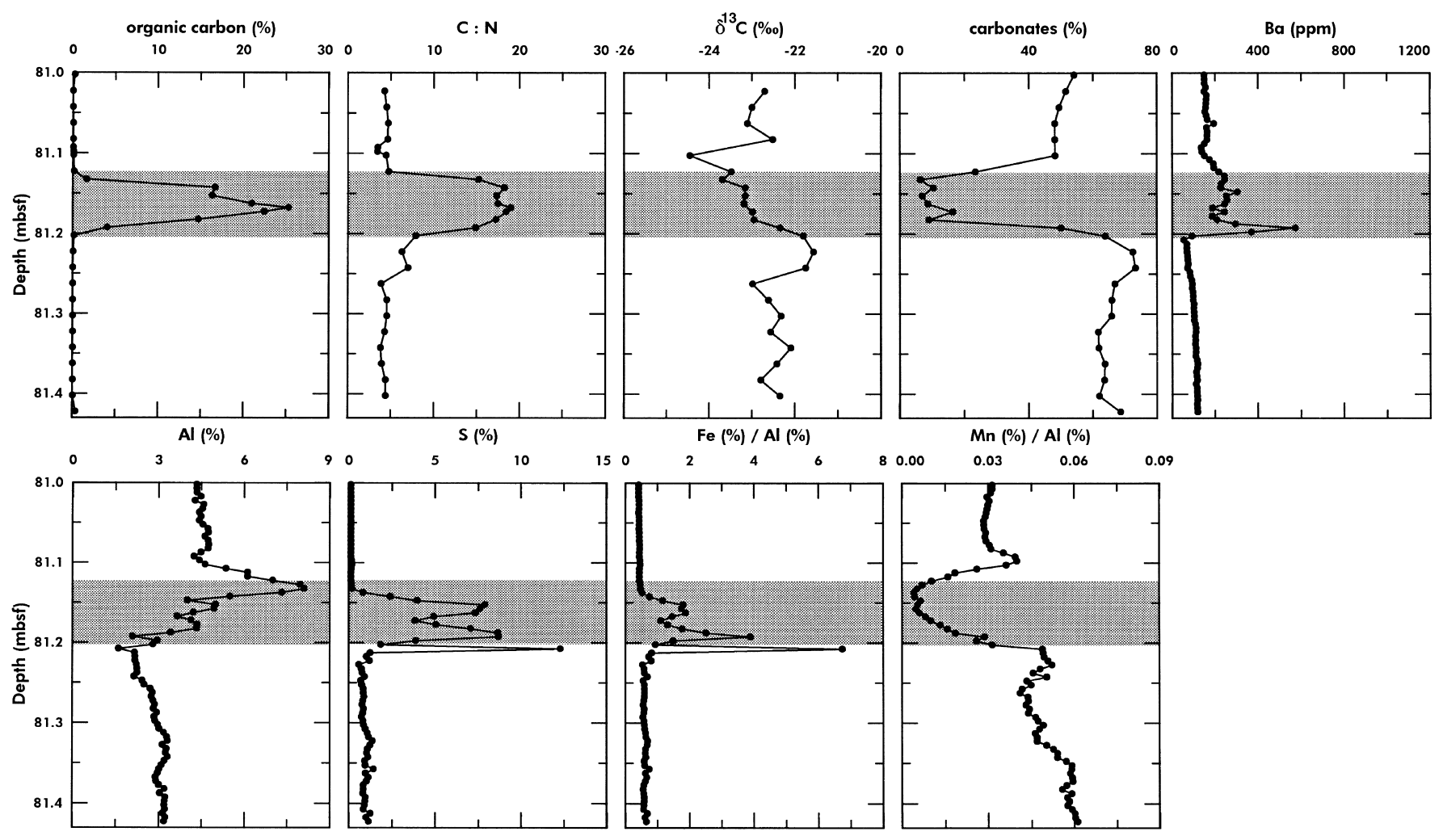

Figure 1. Organic carbon, $\mathrm{C} / \mathrm{N}$ value, $\delta^{13} \mathrm{C}(\mathrm{PDB})$, carbonate, $\mathrm{Ba}, \mathrm{Al}, \mathrm{S}, \mathrm{Fe} / \mathrm{Al}$, and Mn/Al profiles in interval 964D10/1. All percentages are weight percentages. 

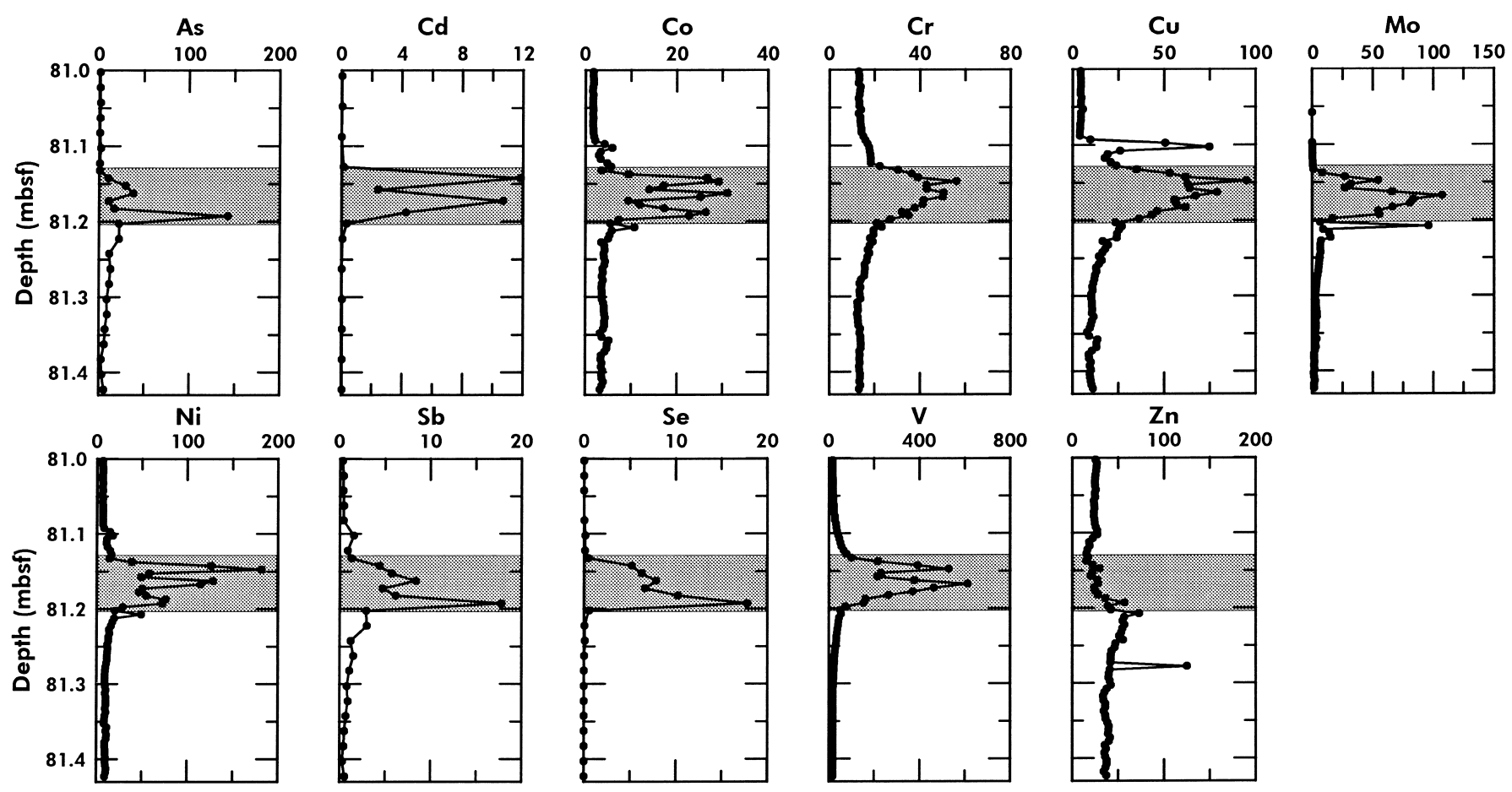

Figure 2. As, $\mathrm{Cd}, \mathrm{Co}, \mathrm{Cr}, \mathrm{Cu}, \mathrm{Mo}, \mathrm{Ni}, \mathrm{Sb}, \mathrm{Se}, \mathrm{V}$, and $\mathrm{Zn}$ profiles in interval 964D10/1. All trace elements are shown as ratios to $\mathrm{Al}$ (ppm/wt\%) to correct for carbonate dilution effects.

Table 2. Average and extreme contents of organic carbon (wt\%) and trace elements (in ppm) in the sapropels, and homogeneous intervals (averages only) of this study.

\begin{tabular}{|c|c|c|c|c|c|c|c|c|c|c|c|c|}
\hline Sample & C-org & As & $\mathrm{Cd}$ & Co & $\mathrm{Cr}$ & $\mathrm{Cu}$ & Mo & $\mathrm{Ni}$ & $\mathrm{Sb}$ & $\mathrm{Se}$ & $\mathrm{V}$ & $\mathrm{Zn}$ \\
\hline \multicolumn{13}{|l|}{ 964D10/1 } \\
\hline Mean sapropel & 15.3 & 112 & 34 & 76 & 182 & 264 & 195 & 317 & 26 & 29 & 1317 & 115 \\
\hline Maximum sapropel & 25.3 & 297 & 65 & 147 & 265 & 388 & 392 & 727 & 37 & 44 & 2235 & 142 \\
\hline Mean homogeneous & 0.1 & 20 & 0.3 & 12 & 54 & 47 & 13 & 36 & 3 & 0.2 & 99 & 120 \\
\hline \multicolumn{13}{|l|}{$967 C 8 / 4$} \\
\hline Mean sapropel & 8.4 & 58 & 3 & 48 & 77 & 110 & 202 & 183 & 8 & 22 & 555 & 90 \\
\hline Maximum sapropel & 15.4 & 88 & 8 & 75 & 96 & 138 & 410 & 251 & 17 & 38 & 884 & 114 \\
\hline Mean homogeneous & 0.1 & 22 & 0.1 & 19 & 46 & 48 & 32 & 51 & 2 & 0.4 & 99 & 55 \\
\hline \multicolumn{13}{|l|}{ 969Е6/6 } \\
\hline Mean sapropel & 17.7 & 41 & 31 & 37 & 168 & 207 & 407 & 299 & 9 & 24 & 1937 & 163 \\
\hline Maximum sapropel & 27.3 & 62 & 88 & 66 & 197 & 334 & 728 & 382 & 14 & 36 & 3575 & 181 \\
\hline Mean homogeneous & 0.2 & 13 & 0.1 & 14 & 96 & 53 & 16 & 80 & 2 & 1 & 99 & 135 \\
\hline \multicolumn{13}{|l|}{ 964E6/5 } \\
\hline Mean sapropel & 12.0 & & 22 & 112 & 245 & 265 & 151 & 280 & & & 923 & 121 \\
\hline Maximum sapropel & 24.2 & & 55 & 206 & 414 & 378 & 363 & 379 & & & 2061 & 161 \\
\hline Mean homogeneous & 0.1 & & 0.1 & 19 & 45 & 47 & 6 & 40 & & & 75 & 43 \\
\hline \multicolumn{13}{|l|}{$966 \mathrm{C} 5 / 3$} \\
\hline Mean sapropel & 6.0 & & 1 & 22 & 47 & 74 & 133 & 101 & & & 340 & 57 \\
\hline Maximum sapropel & 11.6 & & 3 & 46 & 61 & 137 & 295 & 159 & & & 797 & 42 \\
\hline Mean homogeneous & 0.3 & & 0.1 & 0 & 38 & 31 & 7 & 37 & & & 84 & 86 \\
\hline \multicolumn{13}{|l|}{$967 C 8 / 6$} \\
\hline Mean sapropel & 13.2 & & 8 & 35 & 76 & 135 & 224 & 174 & & & 918 & 98 \\
\hline Maximum sapropel & 20.3 & & 18 & 59 & 90 & 177 & 515 & 327 & & & 1630 & 144 \\
\hline Mean homogeneous & 0.2 & & 0.2 & 17 & 57 & 51 & 13 & 49 & & & 126 & 58 \\
\hline
\end{tabular}

negative $\delta^{18} \mathrm{O}_{\text {carb }}$ values of planktonic foraminiferal tests (indicating a low-salinity surface-water layer that reduces deep-water circulation), and higher concentrations of redox-sensitive and chalcophilic trace elements. Because the sapropels in this study show indications for both increased productivity (high Ba contents) and better preservation (laminae, high trace element concentrations), both factors were probably important during sapropel formation.

The enrichment of trace elements in marine sediments may originate from five different sources:

1. super- and subjacent sediments, through diagenesis;
2. hydrothermal vents;
3. windborne input;
4. rivers; or
5. seawater.

By discussing these sources separately, we will attempt to determine which factors contributed to the extreme enrichments observed in the i-282 sapropel. To assess their relative importance, the trace element budget of the Eastern Mediterranean during the formation of this sapropel will be approximated. The accompanying calculations will be simplified by taking the average composition and thickness of 
the sapropel at the three sites and interpolating and extrapolating its occurrence between and around these locations. The sites span most of the width of the Eastern Mediterranean, but we will leave one third of the sea uncovered to account for areas (e.g., shallow) in which sapropels may be less well developed.

It would be convenient to know the duration of sapropel formation. Calculating this period from a $46-\mathrm{cm}$-thick cycle, a $12-\mathrm{cm}$ mean sapropel thickness, and the 22-k.y. duration of Cycle 282, a value of 5.7 k.y. is obtained. This method, however, does not allow for differences in sedimentation rate or diagenetic changes in thickness. Taking into account a decrease in sedimentation rate during sapropel formation, Wehausen and Brumsack (Chap. 17, this volume) calculate sapropel-duration estimates of 2-6 k.y. for Pliocene sapropels from Site 967. Estimates for the duration of the most recent sapropel (S1), which can be dated directly, but is strongly affected by diagenetic thinning, are between 3 (Hilgen et al., 1993) and 4 k.y. (Van Santvoort et al., 1996). Thus, we cannot approximate the duration of the i-292 sapropel any better than between 3 and 6 k.y.

\section{Super- and Subjacent Sediments, Through Diagenesis}

During formation, the sapropels are anoxic sulfidic (Passier et al., 1996; Passier and de Lange, Chap. 20, this volume), whereas the homogeneous sediments beneath are postoxic (Van Santvoort et al., 1996). The sapropels may, therefore, act as sinks for chalcophilic elements (which coprecipitate with Fe sulfides) and redox-sensitive elements (which are immobilized under anoxic conditions), which are mobilized in the postoxic parts of the sediment (e.g., Thomson et al., 1995). In this way, trace elements can become enriched in the sapropels. However, the sapropels may also be affected by a downward-moving oxidation front ("burn-down front"). This occurs when, after sapropel deposition, bottom-water oxygen diffuses into the TOC- and iron-sulfide-rich sediment (Wilson et al., 1985; Higgs et al., 1994; Van Santvoort et al., 1996). As a result of oxidation of this organic matter and the sulfides, trace element peaks that were originally located in TOC-rich sediment, may end up in TOC-poor sediment (Thomson et al., 1995; Nijenhuis et al., 1996). Furthermore, Mn and Fe oxyhydroxides that precipitated as a result of such a burndown front may provide a temporary alternative sink for the trace elements, because of coprecipitation or sorption. This may explain the observation that trace element peaks are not only found within the sapropels, but also above them, although $\mathrm{Fe}$ and $\mathrm{Mn}$ oxyhydroxides are no longer present. Trace element peaks below the sapropels may be the result of coprecipitation with pyrite formed as a result of downward sulfidization (Passier et al., 1996).

If we assume that the trace element peaks in the sediment are caused by diagenesis alone, then we can calculate the original concentration by redistributing the total trace element amount equally over homogeneous and sapropel intervals. This method of calculation results in very high average contents (Table 3 ). If we compare these values with trace element concentrations from other studies (e.g., Calvert, 1983; Sutherland et al., 1984; Pruysers et al., 1991; Van der Weijden et al., 1993; Nijenhuis et al., 1996), we find that they are similar to the average (sometimes even the maximum) concentrations found in the sapropels of these studies. Furthermore, we have done the same calculation for other sapropels in the same cores (Table 3). The average concentrations obtained for those sapropels are quite different from those of $\mathrm{i}-282$, whereas we would expect them to be the same if diagenesis caused the enrichment. These comparisons show that this type of diagenesis can be ruled out as the single source of the trace element excess in the sapropel.

Another way in which diagenesis can lead to an enrichment of trace elements is by the dissolution of carbonate and/or opal. The micropaleontology of the sapropel in interval 969E6/6 is characterized by the virtual absence of foraminifers (L.J. Lourens, pers. comm., 1996). Benthic life was probably inhibited by bottom-water anoxia at times of sapropel formation, but the absence of planktonic foramini-
Table 3. Contents obtained when averaging out the trace element contents in intervals 964D10/1, 964E6/5, 966C5/3, 966C5/4 (160-966C-5H-4, 25-65 cm), 967C8/4, 967C8/6, 969E6/1 (160-969E-6H-1, 110-150 cm, combined with 160-969E-6H-2, 0-20 cm), and 969E6/6.

\begin{tabular}{lcrrrrrrr}
\hline Interval & $\mathrm{Cd}$ & $\mathrm{Co}$ & $\mathrm{Cr}$ & $\mathrm{Cu}$ & $\mathrm{Mo}$ & $\mathrm{Ni}$ & $\mathrm{V}$ & $\mathrm{Zn}$ \\
\hline $964 \mathrm{D} 10 / 1$ & 9 & 23 & 75 & 82 & 41 & 83 & 299 & 119 \\
$964 \mathrm{E} 6 / 5$ & 2 & 29 & 68 & 72 & 27 & 68 & 173 & 52 \\
$966 \mathrm{C} 5 / 3$ & & 15 & 42 & 51 & 67 & 67 & 206 & 49 \\
$966 \mathrm{C} 5 / 4$ & & 12 & 36 & 47 & 33 & 52 & 218 & 43 \\
$967 \mathrm{C} 8 / 4$ & 1 & 27 & 54 & 64 & 92 & 84 & 213 & 64 \\
$967 \mathrm{C} 8 / 6$ & 4 & 26 & 66 & 93 & 116 & 110 & 512 & 77 \\
$969 \mathrm{E} 6 / 1$ & & 53 & 72 & 68 & 37 & 126 & 241 & 53 \\
$969 \mathrm{E} 6 / 6$ & & 23 & 127 & 119 & 182 & 173 & 879 & 147 \\
\hline
\end{tabular}

Note: All numbers are in parts per million.

fers can only be explained by carbonate dissolution during diagenesis. Carbonate dissolution probably also was important in the sapropels at the other sites. The removal of $\sim 30 \% \mathrm{CaCO}_{3}$ (the average difference between sapropel and homogeneous sediment from all intervals) will increase the trace element content in the sapropels by a factor of 1.4, unless large amounts of $\mathrm{Ca}$ are reprecipitated as gypsum. However, only limited amounts of gypsum were found (Passier and de Lange, Chap. 20, this volume). The factor of 1.4 is not used in our calculations as these are performed using total trace element quantities rather than concentrations.

Opal has not been measured in our samples, but is probably absent because this mineral readily dissolves under normal marine conditions. However, when the sapropel was formed, it may have contained the high amounts of opal typically associated with sediments underlying high-productivity areas. Nevertheless, like carbonate, opal merely acts as a temporary diluting agent. When it dissolves, the trace element concentration will increase, but the total amount, which we use for the calculations, will remain the same.

\section{Hydrothermal Vents}

The cyclic occurrence of sapropels in the Mediterranean region is not likely to be the result of hydrothermal activity, but the total amount of trace elements available will be higher in a geological period of increased hydrothermal activity. This mechanism can be ruled out, however, because $\mathrm{Zn}$, an element that is typically associated with hydrothermal activity (e.g., James and Elderfield, 1996), is not enriched in the sapropels, whereas nonhydrothermal elements, such as Mo and V (Bjornsson et al., 1972), are enriched.

\section{Windborne Input}

Estimates for the contribution of wind-derived material in Mediterranean sediments are highly variable, thus windborne input is a potentially important trace element source. However, in the orbital forcing model, sapropels are formed during wet climatic conditions, when windborne input is likely to be lower rather than higher. Evidence for lower windborne input during sapropel formation is presented by Wehausen and Brumsack (Chap. 17, this volume) and Foucault and Mélières (1995).

\section{Rivers}

As the trace element concentrations in river water are presumably rather low, and the water volumes supplied to oceans by rivers are relatively small, a special setting and long periods of time are needed for river water to be the main source of trace elements in marine sediments.

Unfortunately, no good data for the trace element input of rivers into the Mediterranean are available. Data from recent trace element studies are affected by anthropogenic contributions, whereas in older 
studies, these elements were neither sampled contamination-free nor measured accurately enough. Therefore, data for the mean world river composition (Broecker and Peng, 1982; Martin and Whitfield, 1983; Brumsack, 1989) are used for the following calculations. The actual trace element concentrations of Pliocene river input into the Mediterranean may have been quite different, but the data will suffice for an order-of-magnitude calculation. Because climatic conditions during precession minima are more humid (e.g., Rohling and Hilgen, 1991), river input into the Mediterranean is likely to be significantly higher during sapropel formation than at present. Furthermore, the sharp contrast in climate during precession minima (humid) and maxima (arid) may lead to a higher trace metal load of circum-Mediterranean rivers (Wehausen and Brumsack, Chap. 17, this volume).

Assuming a 50\% increase of present fluvial input (including the amount coming through the Bosporus from the present Black Sea, which was a freshwater lake in the Pliocene), and the incorporation of all trace elements supplied by rivers into the sediment, long periods of river input into the Mediterranean are needed to supply the amounts of trace elements present in the sapropel (Table 4). Except for As and $\mathrm{Sb}$, these values are unrealistically high if we assume a sapropel formation time of several thousand years. Even a doubling of the river flux or the trace metal concentration of the fluvial input would not provide the amounts of trace metals that are actually found in the sapropel, within a reasonable time period.

\section{Seawater}

Although the concentration of trace elements in seawater is low, the reservoir is large, so high total amounts are available. Based on mean seawater trace-metal concentrations (Broecker and Peng, 1982; Bruland, 1983), we calculated the amount of seawater that must be stripped of its trace element content to explain the composition of the sapropel (expressed in Eastern Mediterranean Sea volumes; Table 4). For most trace metals, $<50$ times the trace element amount already present in the Eastern Mediterranean is sufficient. At first glance, this seems to be an enormous amount, but based on the current water input from the Western Mediterranean of $39,800 \mathrm{~km}^{3} \mathrm{yr}^{-1}$ (Bethoux, 1980), only $\sim 4$ k.y. of exchange with this basin are necessary (Table 4).

One of the key elements for this calculation certainly is vanadium. Its seawater concentration is well known, and its river-water concentration ranges from 0.5 to $1.0 \mathrm{ng} / \mathrm{g}$ (i.e., generally lower than in sea- water; Shiller and Boyle, 1987). The time necessary for the accumulation of $\mathrm{Cr}, \mathrm{Cu}$, and $\mathrm{Ni}$ is comparable to that of $\mathrm{V}$. For $\mathrm{As}, \mathrm{Mo}, \mathrm{Sb}$, and $\mathrm{Zn}$, the seawater reservoir is sufficiently large to explain the ranges observed. The only element that does not fit this pattern is Co. Because this element is closely associated with $\mathrm{Mn}$, another enrichment mechanism, possibly related to the dissolution of Mn oxyhydroxides in post-oxic shelf sediments as a result of a fluctuating oxicanoxic interface, may play a role. This type of mechanism has been found to operate for Mn in the Black Sea and may also affect other heavy metals (Kempe et al., 1991). Despite this minor discrepancy, seawater certainly is the most likely source of the trace metal enrichments observed in the sapropel layers.

However, both for the river-water and the seawater source, a mechanism must still be postulated that transfers the trace elements from the dissolved phase to the particulate phase. A major removal process is the uptake of trace elements by planktonic species, followed by their sedimentation. Marine organisms can "bioconcentrate" trace elements up to $10^{5}$ times the average seawater concentration (Martin and Knauer, 1973; Collier and Edmond, 1984). However, the trace element content of plankton (Table 4) never reaches the high values observed in the sapropels (Table 4). Such metal contents are also never attained in sediments underlying modern upwelling regions. The concentration of the trace elements may increase in organic matter raining down to the ocean floor: the organic material is degraded, and the elements become enriched in the residue. As little as $3 \%$ of the primary production may actually be preserved in anoxic sediments (Tyson, 1995). If all trace elements remain in this residue, a maximum enrichment factor of 33 can be attained. However, this assumption ignores the fact that most metals are regenerated in the water column even at shallow depths (Bruland, 1983). Thus, except perhaps for $\mathrm{Zn}$, another process is definitely required to explain the high trace element content of the sapropel.

Because of the redox-sensitive and chalcophilic nature of the trace elements discussed, they can be bound to organic matter $(\mathrm{Cr}, \mathrm{Mo}, \mathrm{V})$, or can coprecipitate with (or form their own) sulfides (As, Cd, Co, $\mathrm{Cu}, \mathrm{Ni}, \mathrm{Zn}$ ) under reducing conditions. Therefore, if part of the water column becomes anoxic, or if seawater slowly circulates through the oxic-anoxic interface, trace elements may be transferred from seawater to the sediment by sulfides and organic matter. Indeed, previous workers proved that the concentrations of $\mathrm{Cd}, \mathrm{Cu}, \mathrm{Mo}, \mathrm{Se}, \mathrm{V}$, and $\mathrm{Zn}$ in anoxic seawater are considerably lower (although not zero) than in oxic seawater (Pilipchuk and Volkov, 1974; Jacobs and Emerson,

Table 4. Results of calculations for establishing the possible sources of the trace elements in Sapropel i-292.

\begin{tabular}{|c|c|c|c|c|c|c|c|c|c|c|}
\hline $\begin{array}{c}\text { Trace } \\
\text { element }\end{array}$ & $\begin{array}{l}\text { Excess } \\
\text { content } \\
(\mathrm{ppm})^{*}\end{array}$ & $\begin{array}{c}\text { Total } \\
\text { quantity } \\
\left(10^{12} \mathrm{~g}\right) \dagger\end{array}$ & $\begin{array}{c}\text { Content } \mathrm{C}_{\text {org }} \\
\text { sapropel } \\
(\mathrm{ppm})^{* *}\end{array}$ & $\begin{array}{c}\text { Content } \mathrm{C}_{\text {org }} \\
\text { marine organisms } \\
(\mathrm{ppm}) \ddagger\end{array}$ & $\begin{array}{c}\text { Seawater } \\
\text { concentration } \\
(\mathrm{ppb})^{* * *}\end{array}$ & $\begin{array}{c}\text { River water } \\
\text { concentration } \\
(\mathrm{ppb}) \dagger \dagger\end{array}$ & $\begin{array}{l}\text { Total quantity } \\
\text { E. Mediterranean } \\
\left(10^{12} \mathrm{~g}\right)^{* * * *}\end{array}$ & $\begin{array}{c}\text { Water volume } \\
\text { needed } \\
\text { (number } \times \text { E. Med.) } \dagger+\end{array}$ & $\begin{array}{l}\text { Period river } \\
\text { input needed } \\
(\mathrm{k} . \mathrm{y} .)^{\wedge}\end{array}$ & $\begin{array}{l}\text { Period seawater } \\
\text { input needed } \\
(\mathrm{k} . \mathrm{y} .)^{\wedge \wedge}\end{array}$ \\
\hline As & 51 & 12 & 371 & 12.5 & 1.7 & 1.7 & 4.34 & 3 & 3 & 0.1 \\
\hline $\mathrm{Cd}$ & 22 & 5 & 159 & 30 & 0.08 & 0.02 & 0.20 & 26 & 188 & 1.7 \\
\hline Co & 39 & 10 & 286 & 2.5 & 0.001 & 0.2 & 0.003 & 3779 & 35 & 253 \\
\hline $\mathrm{Cr}$ & 88 & 21 & 638 & 5 & 0.21 & 1 & 0.54 & 40 & 15 & 2.6 \\
\hline $\mathrm{Cu}$ & 150 & 37 & 1091 & 27.5 & 0.25 & 1.5 & 0.63 & 58 & 18 & 3.8 \\
\hline Mo & 257 & 63 & 1868 & 5 & 10.6 & 0.5 & 27.03 & 2 & 52 & 0.089 \\
\hline $\mathrm{Ni}$ & 224 & 55 & 1627 & 18.75 & 0.47 & 0.5 & 1.19 & 46 & 78 & 3.0 \\
\hline $\mathrm{Sb}$ & 12 & 3 & 86 & 1.25 & 0.15 & 1 & 0.38 & 8 & 2 & 0.4 \\
\hline $\mathrm{Se}$ & 25 & 6 & 179 & 2.5 & 0.14 & 0.2 & 0.35 & 17 & 21 & 1.1 \\
\hline V & 1206 & 296 & 8781 & 9 & 1.8 & 0.77 & 4.59 & 64 & 276 & 4.3 \\
\hline $\mathrm{Zn}$ & 21 & 5 & 151 & 275 & 0.39 & 0.35 & 0.99 & 5 & 9 & 0.3 \\
\hline
\end{tabular}

Notes: Calculations based on a virtual sapropel, which has a composition that is the average of the three sites, a thickness of $12 \mathrm{~cm}$, and a dry density of $1.8 \mathrm{~g} / \mathrm{cm}^{3}$, and which covers $2 / 3$ of the Eastern Mediterranean. Homogeneous values have been calculated in the same way. * = excess trace element content of the sapropel (the content of the sapropel minus the content of the homogeneous). $\dagger=$ the total trace element amount of the sapropel. $* *=$ the trace element content of the organic carbon present in the sapropel assuming that all trace elements are fixed to organic matter. $\neq=$ the trace element content of marine organic matter converted to marine organic carbon by multiplication with 2.5 (assuming that the dry matter of marine organisms contains $40 \%$ organic carbon), based on Brumsack $(1980,1986)$ and Arthur et al. (1990). *** $=$ the trace element concentration of seawater (Broecker and Peng, 1982; Bruland, 1983). $\dagger \dagger=$ the trace element concentration of river water (Broecker and Peng, 1982; Martin and Whitfield, 1983; Brumsack, 1989). **** = the total trace element amount present in the Eastern Mediterranean Sea with a composition of Column $6 . \neq \neq=$ the trace element quantity present in the sapropel expressed in multiples of the amount present in the Eastern Mediterranean. ${ }^{\wedge}=$ the number of years of river input needed to supply the amount of trace elements present in the sapropel to the Mediterranean, based on a river composition as in Column 7, and 1.5 times today's riverine input of $514 \mathrm{~km}^{3} / \mathrm{yr}$ plus $400 \mathrm{~km}^{3} / \mathrm{yr}$ from the Black Sea (Lacombe and Tchernia, 1972). The trace elements already present in the Eastern Mediterranean have been deducted from the sapropel total; trace element fixation in the Western Mediterranean is neglected. $\wedge \wedge=$ the number of years that water exchange with the Western Mediterranean is needed to supply the excess trace element content of the sapropel. The trace elements present in the Mediterranean have already been deducted from the sapropel total. The water input from the Western Mediterranean is $39,800 \mathrm{~km}^{3} \mathrm{yr}^{-1}(\mathrm{Bethoux}, 1980)$. 
1983; Collier, 1984; Takayanagi and Wong, 1985). This concept has often been advanced to explain trace element enrichments in organicrich sediments (e.g., Brumsack, 1980; Arthur et al., 1990; Calvert and Pedersen, 1993; Van der Weijden, 1993) and seems to be the most likely mechanism in this Pliocene Mediterranean sapropel as well.

Bosch et al. (Chap. 23, this volume), in their organic geochemical studies of the i-282 sapropel from Hole 969E, demonstrated that the water column was euxinic up into the photic zone. A consequence of this finding is that the calculated time of seawater supply is too low, for two reasons. First, the concentration of trace elements in anoxic seawater was not zero. Second, anoxia most likely developed under stagnant conditions, in a stratified water column, when water exchange with the Western Mediterranean was probably lower than the modern value used. An elegant way around this problem is a model that invokes circulation reversal in the Eastern Mediterranean from anti-estuarine during periods in which homogeneous sediment is deposited to estuarine during sapropel formation (Calvert, 1983; Buckley and Johnson, 1988; Thunell and Williams, 1989). Such a circulation pattern would result from a decrease of surface-water salinity caused by increased river input and would act as a nutrient trap. Based on nutrient balance calculations of the S1 sapropel, Sarmiento et al. (1988) showed that, with a reversed circulation pattern in the Eastern Mediterranean Sea, the water column will inevitably become anoxic, while the Western Mediterranean can remain oxic. Thus, a model with reversed circulation in the Eastern Mediterranean during sapropel formation may explain the high trace element contents in the sediment by the anoxic water column, while trace elements continue to be added from the adjacent basins and by rivers. The very high organic matter content can also be explained by nutrient trapping during estuarine circulation, which leads to increased productivity and to high organic matter accumulation rates. Preservation of this organic matter may be promoted by anoxic conditions. However, the trace element budget estimated in this study provides only circumstantial indications for such a reversal, and to substantiate this concept, additional evidence must be provided by further organic geochemical and sedimentological research.

In summary, it has been argued that diagenesis can explain only a small fraction of the trace element enrichment in the sapropels, thus, the largest part of the signal is authentic. Wind input and hydrothermal activity are not likely to be responsible for the trace element enrichments found in the sapropels. The trace element amounts in the sediment cannot be supplied by rivers in a reasonable time period, unless the trace element content and runoff were very much higher than assumed in the calculations. The large uncertainties in the river input during times of sapropel formation and the essentially unknown trace metal concentration of this water should not be disregarded. Nevertheless, we have increased the fluvial input by up to a factor of five without significantly changing the overall budget. The same is true for changing the river-water composition by a factor of five. The calculations further show that seawater can supply enough trace elements (except for Co), unless water exchange at the Straits of Sicily is very much restricted.

For comparison, these calculations were also applied to the i-292 sapropel at Sites 964, 966, and 967. Although the time intervals calculated (Table 5) are shorter than for i-282, the basic outcome is the same: rivers cannot supply the trace elements in a reasonable time period, and several thousand years of seawater exchange with the Western Mediterranean is necessary for most trace elements. The differences in the time periods calculated can partly be explained by the fact that Site 966, in which sapropels are less well developed, is not included in the calculations for Sapropel i-282, whereas Site 969, in which sapropels are well developed, is not included in the calculations for Sapropel i-292.

All in all, the trace element budget appears to be reasonably accurate, although rather tight. A very large fraction of the trace elements supplied to the Eastern Mediterranean during sapropel formation apparently ended up in the sediment. This implies that an efficient trace element removal mechanism must have operated during the formation of this and several other Pliocene sapropels. We propose that this mechanism was widespread anoxia in the Eastern Mediterranean during the formation of these sapropels. In this way, a large part of the trace elements that entered the Mediterranean from several different sources could be transferred to the sediment.

\section{CONCLUSIONS}

Several Pliocene sapropels are characterized by extremely high $\mathrm{C}_{\text {org }}$ and trace element contents. The $\mathrm{C}_{\text {org }}$ enrichment results from both increased productivity and better preservation. The excess trace elements in the sapropels mainly originated from seawater, but rivers also played a role. Diagenesis, wind input, and hydrothermal activity did not contribute significantly to the excess. An efficient trace element removal mechanism, most likely widespread anoxia, operated during Pliocene sapropel formation.

Table 5. Results of calculations for establishing the possible sources of the trace elements in Sapropel i-292

\begin{tabular}{|c|c|c|c|c|c|c|c|c|c|c|}
\hline $\begin{array}{l}\text { Trace } \\
\text { element }\end{array}$ & $\begin{array}{l}\text { Excess } \\
\text { content } \\
(\mathrm{ppm}) *\end{array}$ & $\begin{array}{c}\text { Total } \\
\text { quantity } \\
\left(10^{12} \mathrm{~g}\right) \dagger\end{array}$ & $\begin{array}{c}\text { Content } \mathrm{C}_{\text {org }} \\
\text { sapropel } \\
(\mathrm{ppm})^{* *}\end{array}$ & $\begin{array}{l}\text { Content } \mathrm{C}_{\text {org }} \\
\text { marine organisms } \\
(\mathrm{ppm}) \ddagger\end{array}$ & $\begin{array}{c}\text { Seawater } \\
\text { concentration } \\
(\mathrm{ppb})^{* * *}\end{array}$ & $\begin{array}{c}\text { River water } \\
\text { concentration } \\
(\mathrm{ppb}) \dagger \dagger\end{array}$ & $\begin{array}{l}\text { Total quantity } \\
\text { E. Mediterranean } \\
\left(10^{12} \mathrm{~g}\right)^{* * * *}\end{array}$ & $\begin{array}{c}\text { Water volume } \\
\text { needed } \\
\text { (number } \times \text { E. Med.) } \neq \dagger\end{array}$ & $\begin{array}{c}\text { Period river } \\
\text { input needed } \\
(\mathrm{k} . \mathrm{y} .)^{\wedge}\end{array}$ & $\begin{array}{l}\text { Period seawater } \\
\text { input needed } \\
(\mathrm{k} . \mathrm{y} .)^{\wedge \wedge}\end{array}$ \\
\hline $\mathrm{Cd}$ & 8 & 2 & 74 & 30 & 0.08 & 0.02 & 0.20 & 12 & 81 & 0.7 \\
\hline Co & 26 & 8 & 250 & 2.5 & 0.001 & 0.2 & 0.003 & 3238 & 30 & 217 \\
\hline $\mathrm{Cr}$ & 46 & 15 & 445 & 5 & 0.21 & 1 & 0.54 & 27 & 10 & 1.8 \\
\hline $\mathrm{Cu}$ & 88 & 28 & 845 & 27.5 & 0.25 & 1.5 & 0.64 & 44 & 13 & 2.9 \\
\hline Mo & 169 & 53 & 1614 & 5 & 10.6 & 0.5 & 27.03 & 2 & 39 & 0.065 \\
\hline $\mathrm{Ni}$ & 121 & 38 & 1159 & 18.75 & 0.47 & 0.5 & 1.20 & 32 & 54 & 2.1 \\
\hline V & 603 & 191 & 5777 & 9 & 1.8 & 0.77 & 4.59 & 42 & 176 & 2.7 \\
\hline $\mathrm{Zn}$ & 40 & 13 & 382 & 275 & 0.39 & 0.35 & 0.99 & 13 & 24 & 0.8 \\
\hline
\end{tabular}

Notes: Calculations based on a virtual sapropel, which has a composition that is the average of the three sites, a thickness of $16 \mathrm{~cm}$, and a dry density of $1.8 \mathrm{~g} / \mathrm{cm}{ }^{3}$, and which covers $2 / 3$ of the Eastern Mediterranean. Homogeneous values have been calculated in the same way. $*=$ excess trace element content of the sapropel (the content of the sapropel minus the content of the homogeneous. $\dagger=$ the total trace element amount of the sapropel. $* *=$ the trace element content of the organic carbon present in the sapropel assuming that all trace elements are fixed to organic matter. $\neq=$ the trace element content of marine organic matter converted to marine organic carbon by multiplication with 2.5 (assuming that the dry matter of marine organisms contains $40 \%$ organic carbon), based on Brumsack $(1980,1986)$ and Arthur et al. (1990). *** $=$ the trace element concentration of seawater (Broecker and Peng, 1982; Bruland, 1983). $\dagger \dagger=$ the trace element concentration of river water (Broecker and Peng, 1982; Martin and Whitfield, 1983; Brumsack, 1989). **** $=$ the total trace element amount present in the Eastern Mediterranean Sea with a composition of Column $6 .+\neq=$ the trace element quantity present in the sapropel expressed in multiples of the amount present in the Eastern Mediterranean. ${ }^{\wedge}=$ the number of years of river input needed to supply the amount of trace elements present in the sapropel to the Mediterranean, based on a river composition as in Column 7, and 1.5 times today's riverine input of $514 \mathrm{~km}^{3} / \mathrm{yr}$ plus $400 \mathrm{~km}^{3} / \mathrm{yr}$ from the Black Sea (Lacombe and Tchernia, 1972). The trace elements already present in the Eastern Mediterranean have been deducted from the sapropel total; trace element fixation in the Western Mediterranean is neglected. $\wedge \wedge=$ the number of years that water exchange with the Western Mediterranean is needed to supply the excess trace element content of the sapropel. The trace elements present in the Mediterranean have already been deducted from the sapropel total. The water input from the Western Mediterranean is $39,800 \mathrm{~km}^{3} \mathrm{yr}^{-1}\left(\mathrm{Bethoux}^{1}, 1980\right)$. 


\section{ACKNOWLEDGMENTS}

I am grateful for Lucas Lourens' help in choosing and sampling the sapropels. I would like to thank John Thomson, Kay-Christian Emeis, and two anonymous reviewers for their helpful suggestions. Veit, Rachel, and Doris are thanked for their cooperation permitting timely sampling in Bremen. This research was funded by the Netherlands Organisation for Scientific Research (NWO), by Grant \#75019-421 to I. Nijenhuis, and by the German Science Foundation (ODP SPP). This is publication \#970132 of the Netherlands School of Sedimentary Geology.

\section{REFERENCES}

Arthur, M.A., Brumsack, H.-J., Jenkyns, H.C., and Schlanger, S.O., 1990. Stratigraphy, geochemistry, and paleoceanography of organic carbon-rich Cretaceous sequences. In Ginsburg, R.N., and Beaudoin, B. (Eds.), Cretaceous Resources, Events and Rhythms: Dordrecht (Kluwer), 75-119.

Bethoux, J.-P., 1980. Mean water fluxes across sections in the Mediterranean Sea evaluated on the basis of water and salt budgets and of observed salinities. Oceanol. Acta, 3:79-88.

Bjornsson, S., Arnorsson, S., and Thomasson, J., 1972. Economic evolution of Reykanes Thermal brine area, Iceland. AAPG Bull., 56:2380-2391.

Broecker, W.S., and Peng, T.-H., 1982. Tracers in the Sea: Palisades, NY (Lamont-Doherty Geol. Observ.).

Bruland, K.W., 1983. Trace elements in seawater. In Riley, J.P., and Chester, R. (Eds.), Chemical Oceanography (Vol. 8): London (Academic Press), 157-220.

Brumsack, H.-J., 1980. Geochemistry of Cretaceous black shales from the Atlantic Ocean (DSDP Legs 11, 14, 36 and 41). Chem. Geol., 31:1-25.

- 1986. The inorganic geochemistry of Cretaceous black shales (DSDP Leg 41) in comparison to modern upwelling sediments from the Gulf of California. In Summerhayes, C.P., and Shackleton, N.J. (Eds.), North Atlantic Palaeoceanography. Geol. Soc. Spec. Publ. London., $21: 447-462$.

1989. Geochemistry of recent TOC-rich sediments from the Gulf of California and the Black Sea. Geol. Rundsch., 78:851-882.

Buckley, H.A., and Johnson, L.R., 1988. Late Pleistocene to Recent sediment deposition in the central and Western Mediterranean. Deep Sea Res. Part A, 35:749-766.

Calvert, S.E., 1983. Geochemistry of Pleistocene sapropels and associated sediments from the Eastern Mediterranean. Oceanol. Acta, 6:225-267.

Calvert, S.E., and Pedersen, T.F., 1993. Geochemistry of Recent oxic and anoxic marine sediments: Implications for the geological record. Mar. Geol., 113:67-88.

Cita, M.B., Vergnaud-Grazzini, C., Robert, C., Chamley, H., Ciaranfi, N., and D'Onofrio, S., 1977. Paleoclimatic record of a long deep sea core from the eastern Mediterranean. Quat. Res., 8:205-235.

Collier, R.W., 1984. Particulate and dissolved vanadium in the North Pacific Ocean. Nature, 309:441-444.

Collier, R.W., and Edmond, J., 1984. The trace element geochemistry of marine biogenic particulate matter. Progr. Oceanogr., 13:113-199.

Demaison, G.J., and Moore, G.T., 1980. Anoxic environments and oil source bed genesis. Org. Geochem., 2:9-31.

Emeis, K.-C., Robertson, A.H.F., Richter, C., et al., 1996. Proc. ODP, Init. Repts., 160: College Station, TX (Ocean Drilling Program).

Foucault, A., and Mélières, F., 1995. Nature et origine des cycles sédimentaires métriques du Pliocène de 1'Ouest méditerranéen d'après l'étude du contenu terrigène de la Formation Narbone (Punta Piccola, Sicile, Italie). C. R. Acad. Sci. Paris, 321:869-876.

Higgs, N.C., Thomson, J., Wilson, T.R.S., and Croudace, I.W., 1994. Modification and complete removal of eastern Mediterranean sapropels by postdepositional oxidation. Geology, 22:423-426.

Hilgen, F.J., Lourens, L.J., Berger, A., and Loutre, M.F., 1993. Evaluation of the astronomically calibrated time-scale for the late Pliocene and earliest Pleistocene. Paleoceanography, 8:549-565.

Jacobs, L., and Emerson, S., 1983. Partitioning and transport of metals across the $\mathrm{O}_{2}-\mathrm{H}_{2} \mathrm{~S}$ interface in a permanently anoxic basin: Framvaren Fjord, Norway. Geochim. Cosmochim. Acta, 49:1433-1444.
James, R., and Elderfield, H., 1996. Chemistry of ore-forming fluids and mineral formation rates in an active hydrothermal sulfide deposit on the Mid-Atlantic Ridge. Geology, 24:1147-1150.

Kempe, S., Diercks, A.-R., Liebezeit, G., and Prange, A., 1991 Geochemical and structural aspects of the pycnocline in the Black Sea $(R / V$ Knorr 1348 Leg 1, 1988). In Izdar, E., and Murray, J.W. (Eds.), Black Sea Oceanography: Amsterdam (Kluwer Academic), 89-110.

Lacombe, H., and Tchernia, P., 1972. Caractères hydrologiques et circulation des eaux en Méditerranée. In Stanley, D.J. (Ed.), The Mediterranean Sea: a Natural Sedimentation Laboratory: Stroudsburg, PA (Dowden, Hutchinson and Ross), 25-36.

Langereis, C.G., and Hilgen, F.J., 1991. The Rosello composite: a Mediterranean and global reference section for the early to early-late Pliocene. Earth Planet. Sci. Lett., 104:211-225.

Lourens, L.J., Antonarakou, A., Hilgen, F.J., Van Hoof, A.A.M., VergnaudGrazzini, C., and Zachariasse, W.J., 1996. Evaluation of the Plio-Pleistocene astronomical timescale. Paleoceanography, 11:391-413.

Martin, J.H., and Knauer, G.A., 1973. The elemental composition of plankton. Geochim. Cosmochim. Acta, 37:1639-1653.

Martin, J.-M., and Whitfield, M., 1983. The significance of the river input of chemical elements to the ocean. In Wong, C.S., Boyle, E., Bruland, K.W., Burton, J.D., and Goldberg, E.D. (Eds.), Trace Metals in Sea Water: New York (Plenum Press), 265-296.

Nijenhuis, I.A., Schenau, S.J., Van der Weijden, C.H., Hilgen, F.J., Lourens, L.J., and Zachariasse, W.J., 1996. On the origin of upper Miocene sapropelites: a case study from the Faneromeni section, Crete (Greece). Paleoceanography, 11:633-645.

Olausson, E., 1961. Studies of deep-sea cores. Rep. Swed. Deep-Sea Exped., 1947-1948, 8:335-391.

Passier, H.F., Middelburg, J.J., De Lange, G.J., and Van Os, B.J.H., 1996. Diagenetic pyritisation under Eastern Mediterranean sapropels caused by downward sulphide diffusion.Geochim. Cosmochim. Acta, 60:751-763.

Pedersen, T.F., and Calvert, S.E., 1990. Anoxia vs. productivity: what controls the formation of organic-carbon-rich sediments and sedimentary rocks? AAPG Bull., 74:454-466.

Pilipchuk, M.F., and Volkov, I.I., 1974. Behavior of molybdenum in processes of sediment formation and diagenesis in Black Sea. In Degens, E.T., and Ross, D.A. (Eds.), The Black Sea: Geology, Chemistry and Biology. AAPG Mem., 20:542-553.

Pruysers, P.A., De Lange, G.J., and Middelburg, J.J., 1991. Geochemistry of eastern Mediterranean sediments: primary sediment composition and diagenetic alterations. Mar. Geol., 100:137-154.

Rohling, E.J., and Hilgen, F.J., 1991. The eastern Mediterranean climate at times of sapropel formation: a review. Geol. Mijnbouw, 70:253-264.

Rossignol-Strick, M., Nesteroff, W., Olive, P., and Vergnaud-Grazzini, C., 1982. After the deluge: Mediterranean stagnation and sapropel formation. Nature, 295:105-110.

Sarmiento, J., Herbert, T., and Toggweiler, J., 1988. Mediterranean nutrient balance and episodes of anoxia. Global Biogeochem. Cycles, 2:427-444.

Shiller, A.M., and Boyle, E.A., 1987. Dissolved vanadium in rivers and estuaries. Earth Planet. Sci. Lett., 86:214-224.

Sutherland, H.E., Calvert, S.E., and Morris, J.R., 1984. Geochemical studies of the recent sapropel and associated sediment from the Hellenic Outer Ridge, eastern Mediterranean Sea, I. Mineralogy and chemical composition. Mar. Geol., 56:79-92.

Takayanagi, K., and Wong, G.T.F., 1985. Dissolved inorganic and organic selenium in the Orca Basin. Geochim. Cosmochim. Acta, 49:539.

Thomson, J., Higgs, N.C., Wilson, T.R.S., Croudace, I.W., De Lange, G.J., and Van Santfoort, P.J.M., 1995. Redistribution and geochemical behavior of redox-sensitive elements around S1, the most recent Eastern Mediterranean sapropel. Geochim. Cosmochim. Acta, 59:3487-3501.

Thunell, R.C., and Williams, D.F., 1989. Glacial-Holocene salinity changes in the Mediterranean Sea: hydrographic and depositional effects. Nature, 338:493-496.

Tyson, R.V., 1995. Sedimentary Organic Matter: Organic Facies and Palynofacies: London (Chapman \& Hall).

Van der Weijden, C.H., 1993. Geochemical signatures preserved in sediments of the Semaforo and Vrica sections (Calabria, Italy) and their relations with variations of the sedimentary regime. Palaeogeogr., Palaeoclimatol., Palaeoecol., 103:203-221.

Van Os, B.J.H., Lourens, L.J., Hilgen, F.J., de Lange, G.J., and Beaufort, L., 1994. The formation of Pliocene sapropels and carbonate cycles in the Mediterranean: diagenesis, dilution, and productivity. Paleoceanography, 9:601-617. 
Van Santvoort, P.J.M., de Lange, G.J., Thomson, J., Cussen, H., Wilson, T.R.S., Krom, M.D., and Ströhle, K., 1996. Active post-depositional oxidation of the most recent sapropel (S1) in sediments of the Eastern Mediterranean. Geochim. Cosmochim. Acta., 60:4007-4024.

Wilson, T.R.S., Thomson, J., Colley, S., Hydes, D.J., Higgs, N.C., and Sørensen, J., 1985. Early organic diagenesis: the significance of progressive subsurface oxidation fronts in pelagic sediments. Geochim. Cosmochim. Acta., 49:811-822.

Date of initial receipt: 15 January 1997

Date of acceptance: 22 June 1997

Ms 160SR-019 